\title{
Alpha radioactivity level along Tigris River sediments in Baghdad governorate area by using CR-39 SSNTD's
}

\author{
Saadi M. D. Al-Nuzal ${ }^{1}$ (D · Abdul-Hameed M. J. Al-Obaidy ${ }^{1} \cdot$ Sahar Ahmed Amin ${ }^{1}$
}

Received: 25 April 2019 / Accepted: 30 July 2019 / Published online: 7 August 2019

(c) The Author(s) 2019

\begin{abstract}
The alpha activities of sediment samples, collected from selected sites along Tigris River in Baghdad city area from January to November 2015, were measured. The measurements were based on the radon exhalation rate $\mathrm{Bq} \mathrm{m}^{-1}$ from the sediment samples, of $10.00 \mathrm{~g}$ mass. It was found that the higher calculated uranium contents were observed during winter months from November to January, while the lowest one were during summer months from May to September. This difference was attributed to the nature of the sediment samples and anthropogenic activities that affected ecosystem of the river. Uranium content of the samples was increased ongoing towards south of the city due to the effects of huge human activities. The increase in water level of Tigris River during this period possibly related to the melting of snow in the Turkish mountainous region. Higher water stream can remove sediments from the river bottom; this mechanism will be partially responsible for increasing the radioactivity level at downstream of the river.
\end{abstract}

Keywords Tigris River sediments $\cdot$ CR-39 SSNTD $\cdot$ NORM $\cdot$ Baghdad governorate area $\cdot{ }^{238} \mathrm{U} \cdot{ }^{222} \mathrm{Rn}$

\section{Introduction}

The major part of Tigris River basin lies in Iraqi land, and no other subdivision is connected to the south of city of Baghdad, but several channels draw water from the Tigris River in this area for irrigation purposes. The water quality of the river in its basin is primarily threatened by the production of salinity ratios from concentrated irrigated agriculture and high evaporation rates. The average annual flow discharge of the Tigris River is $672 \mathrm{~m}^{3} \mathrm{~s}^{-1}$ when it enters Iraq, further tributaries of inside Iraq of $786 \mathrm{~m}^{3} \mathrm{~s}^{-1}$, as well as $222 \mathrm{~m}^{3} \mathrm{~s}^{-1}$ from minor wadies in Iran (Al-Ansari and Knutsson 2011; UN-ESCWA 2013). The water level of the river increases during April because of snow melting in the Turkish mountainous region. Many nutrients, contaminants and natural radionuclides are carried out by the river as sediment particles and are thus transported and deposited with posing risk to society, environment and humans. Such sediments are a complex mixture of materials introduced through rivers' erosion in situ biological or chemical processes and from human sources (Ali

Saadi M. D. Al-Nuzal

saadidhaher@yahoo.com

1 Environmental Research Centre, The University of Technology, Baghdad, Iraq et al. 2012; Al-Shahrabaly 2008; Al-Ansari et al. 1979; Ali et al. 2012). Humic materials are considered responsible in some manner for scavenging more than fifty elements from water and soil (Rahman et al. 2010). These include nutrient substances, toxic heavy metals, radionuclide (including transuranium series) and halogen. Due to their apparent chemical stability, they contain long-lasting free radicals, which are inorganic-type reducers such as $\mathrm{Fe}(\mathrm{III}), \mathrm{Cd}(\mathrm{II}), \mathrm{Hg}$ (II), $\mathrm{Cr}(\mathrm{VI})$ and $\mathrm{Pu}(\mathrm{VI})$ to name a few. High concentration of iron in the river water made scaling in the boiler of water purification system (Rahman et al. 2010; Mantoura et al. 1978; Dries et al. 2005). Many published articles deals with measuring the concentrations of following metals; $\mathrm{Cd}(\mathrm{II}), \mathrm{Cr}(\mathrm{VI}), \mathrm{Cu}(\mathrm{II})$, $\mathrm{Ni}(\mathrm{II}), \mathrm{Pb}$ (II) and $\mathrm{Zn}$ (II) in the sediments of the Tigris River in Baghdad governorate area. It was found that their level where within the permissible limit of rivers maintaining system and general water from pollution, with an exceptions for $\mathrm{Cd}(\mathrm{II})$, $\mathrm{Cr}$ (VI) and $\mathrm{Pb}$ (II) (Al-Lami and Al-Jaberi 2002; Al Obaidy et al. 2016; Al Obaidy et al. 2015). It is worth to mention an attempt to study the presence of natural radioisotopes $\left({ }^{226} \mathrm{Ra}\right.$, ${ }^{228} \mathrm{Ra},{ }^{224} \mathrm{Ra},{ }^{40} \mathrm{~K}$ and ${ }^{235} \mathrm{U}$ ) indicating no such NORM accumulation and very low concentration of artificial isotope viz. ${ }^{137}$ Cs during past Gulf Wars during 1990 and 2003 (Patiris et al. 2015). The natural radioisotopes, ${ }^{238} \mathrm{U}$ and ${ }^{232} \mathrm{Th}$ series, are the greatest source of internal and external exposure in 
human beings. The natural isotopes ${ }^{238} \mathrm{U}$ and ${ }^{232} \mathrm{Th}$ exhalate ${ }^{222} \mathrm{Rn}$ and ${ }^{226} \mathrm{Rn}$, respectively, as well as their daughters can enter the human body largely through food and water. Radon ${ }^{222} \mathrm{Rn}$ and ${ }^{226} \mathrm{Rn}$ decay products have been classified by the International Agency for Research on Cancer as being carcinogenic to humans (Cogliano et al. 2011). Unfortunately similar reports or studies concern the existence of ${ }^{238} \mathrm{U}$ and ${ }^{232}$ Th series natural radioisotopes in Tigris River sediments.

Generally, sediments in the aquatic ecosystem have been used as environmental indicators due to high stability of the chemical and physical characteristics, and their chemical examination can provide significant information on the assessment of anthropogenic activities (Karadede-Akin and Ünlü 2007). However, the objectives of this work were to measure the radioactivity pattern of sediment samples collected from Tigris River within Baghdad city.

\section{Experimental}

\section{Sediment samples collection and preparation}

In the present work, three sites of Tigris River were selected (Fig. 1); the first site was located at upstream in Al-Taji, while the second site was located in the midstream near The Medical city, and the third site was located at the downstream of Al-Zafurania. Sediment samples were collected every 2 months during the period from November 2013 to June 2014. Samples of with $0-10 \mathrm{~cm}$ thickness were taken from each site. They were taken within the areas always covered with water, using tools for digging, placed in plastic bags, and transported to the laboratory in a cool box. Air-dried sediment samples were powdered with pestle and mortar and then sieved through (2-mm sieve).

\section{The radioactivity measurements}

The radon gas, one of the gaseous uranium daughters, viz. ${ }^{222} \mathrm{Rn}$, emitted from samples in closed containers, can be measured in a plastic containers by using solid-state nuclear track detectors, viz. CR-39 SSNTDs (Al Obaidy et al. 2014; United Nations Scientific Committee on the Effects of Atomic Radiation (UNSCEAR) 2012; Selçuk Zorer et al. 2009). These detectors were positioned in specified heights in the top of the containers (top radius of $2.0 \mathrm{~cm}$ and $1.75 \mathrm{~cm}$, respectively). The dimensions of rectangular CR-39 detectors of $250 \mu \mathrm{m}$ thickness, were $1.5 \mathrm{~cm} \times 1.0 \mathrm{~cm}$ which have been separately placed in the top of the well-closed container, as shown in Fig. 2, and sediment

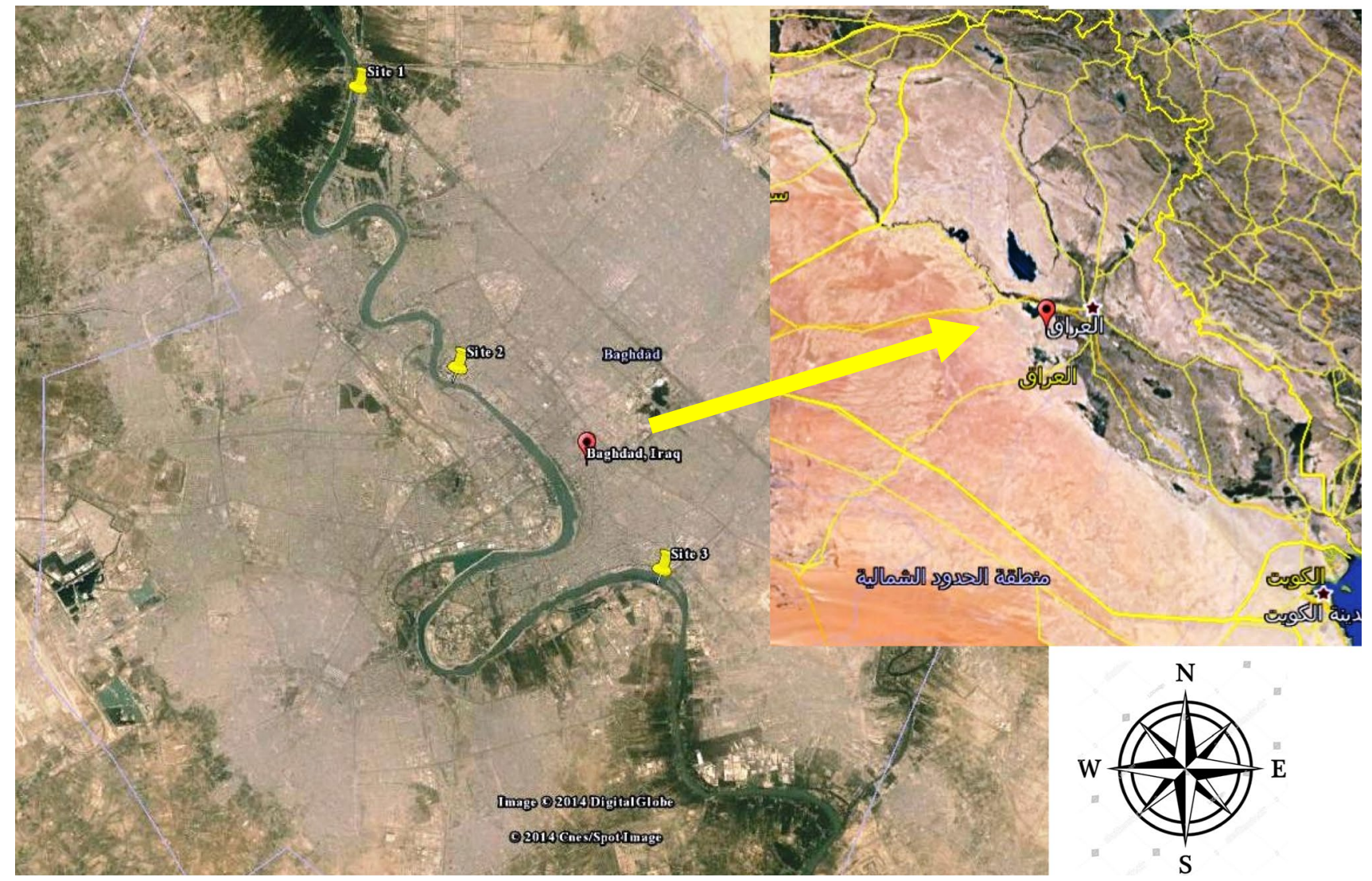

Fig. 1 Map of Iraq and the sediment sampling sites across Tigris River within Baghdad city

كدينة الملك عبدالعزيز

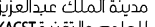


samples of $10.00 \mathrm{~g}$, and were placed in it. The time period to expose the exhalation of radon gas from the samples was 60 days; this will help to accumulate considerable number of $\alpha$-particles tracks. After the exposure, the detectors were developed in $\mathrm{NaOH}$ solution for chemical etching conditions $6.25 \mathrm{~N}$ at $70{ }^{\circ} \mathrm{C}$ for $4 \mathrm{~h}$ for CR-39 films. After the chemical treatment, the visual counting of alpha particles tracks are carried out by means of an optical microscope with power of $400 \times$.

The theoretical calculations of the calibration factor, K, were performed by following the model of Eugin Shaji et al. (2012), as well as that of Sarma (Barillon et al. 1993), for parameters; the fraction of alpha emitters present in air, cup wall dimension, the type of used detector via etching conditions (Sarma 2013; El-Araby 2013). The integrated radon concentration can be calculated from the track density $\rho$ (tracks $\mathrm{cm}^{-2}$ ) which is related to the radon activity concentration $C_{a}\left(\mathrm{~Bq} \mathrm{~cm}^{-3}\right)$ and the exposure time $T$ (days) from formula:

$\rho=K C_{\mathrm{a}} T$ or $C_{\mathrm{a}}=\rho / K T$

where $\rho$ is the track density $\left(\mathrm{Tr} / \mathrm{cm}^{2}\right), K$ is the diffusion constant, $C_{a}$ is the Rn concentration in air space of the cup (Bq/

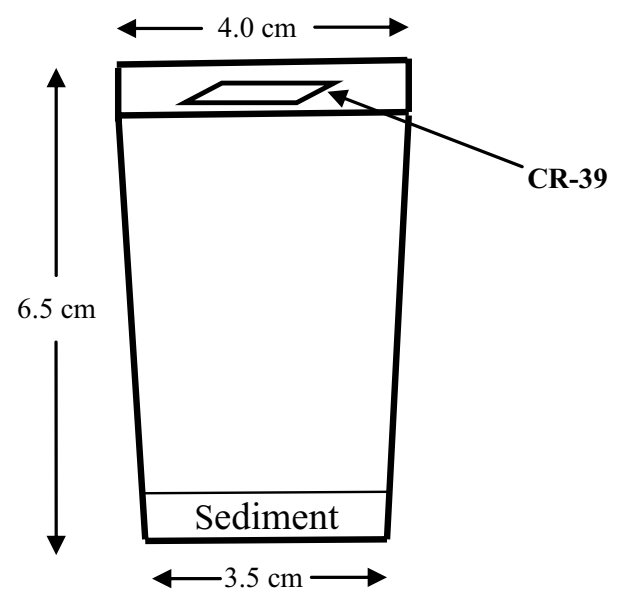

Fig. 2 CR-39 SSNTD's detector used to measure radon exhalation $\left.\mathrm{cm}^{3}\right)$, and $T$ is the radiation time $\mathrm{h}$. Diffusion constant $(K)$ can be determined from the following relation due to the dimensions of the technique:

$K=(1 / 4) r\left[2 \cos \theta_{\mathrm{t}}-r \backslash R_{\alpha}\right]$

where $r$ is the cup average radius for the diffusion volume, $\theta_{\mathrm{t}}$ is the threshold angle for the CR-39 detector $\left(35^{\circ}\right), R_{\alpha}$ is the range of alpha particle in air which is $4.15 \mathrm{~cm}$.

The radon concentration in the samples can be calculated from the following relation:

$C_{\mathrm{s}}=C_{\mathrm{a}} \lambda_{\mathrm{Rn}} H_{\mathrm{t}} / L$

where $C_{s}$ is Rn concentration in the samples $\left(\mathrm{Bq} / \mathrm{m}^{3}\right), C_{a}$ is the $\mathrm{Rn}$ concentration in air space $\left(\mathrm{Bq} / \mathrm{m}^{3}\right), \lambda_{\mathrm{Rn}}$ is the decay constant for $\mathrm{Rn}, H$ is the height of air space in the cup, $L$ is the thickness of the sample, and $t$ is the irradiation time. The activity of radon $A_{\mathrm{Rn}}$ in $\mathrm{Bq}$ exhaled from the sample from the relation:

$A_{\mathrm{Rn}}=C_{s} V \quad$ Where $: V=\pi r^{2} L$

\section{Results and discussion}

The details regarding the alpha activity measurement (expressed in Uranium $\mathrm{Bq} \mathrm{Kg}^{-1}$ ) in sediment samples collected from selected sites along Tigris River from January to November 2015 are given in Table 1. The measurements were based on the radon exhalation rate $\mathrm{Bq} \mathrm{m}^{-1}$ from the sediment samples of $10.00 \mathrm{~g}$ mass. It was found that the obtained average of the measured values of the exhalated radon content of the Tigris River sediments samples for the upstream viz. midstream and downstream sites was found to be $246.63,197.19$ and $262.66 \mathrm{~Bq} \mathrm{~m}^{-1}$, respectively. The calculated average values of uranium content (the only radon ${ }^{222} \mathrm{Ra}$ producing nuclei), for the above three sites, were 3.45 , 2.76 and $3.68 \mathrm{~Bq} \mathrm{Kg}^{-1}$, respectively. Similar observation for the distribution of some heavy metals in sediments samples in Tigris River was observed (Al Obaidy et al. 2016).

Table 1 Alpha radioactivity level in sediment samples collected from Tigris River

\begin{tabular}{|c|c|c|c|c|c|c|c|c|c|}
\hline \multirow[t]{2}{*}{ Months } & \multicolumn{3}{|c|}{ Site 1 (upstream) } & \multicolumn{3}{|c|}{ Site 2 (midstream) } & \multicolumn{3}{|c|}{ Site 3 (downstream) } \\
\hline & $\begin{array}{l}\text { Track } \\
\left(\mathrm{cm}^{-1}\right)\end{array}$ & $\begin{array}{l}\text { Radon } \\
\left(\mathrm{Bq} \mathrm{m}^{-1}\right)\end{array}$ & $\begin{array}{l}\text { Uranium } \\
\left(\mathrm{Bq} \mathrm{Kg}^{-1}\right)\end{array}$ & $\begin{array}{l}\text { Track } \\
\left(\mathrm{cm}^{-1}\right)\end{array}$ & $\begin{array}{l}\text { Radon } \\
\left(\mathrm{Bq} \mathrm{m}^{-1}\right)\end{array}$ & $\begin{array}{l}\text { Uranium } \\
\left(\mathrm{Bq} \mathrm{Kg}^{-1}\right)\end{array}$ & $\begin{array}{l}\text { Track } \\
\left(\mathrm{cm}^{-1}\right)\end{array}$ & $\begin{array}{l}\text { Radon } \\
\left(\mathrm{Bq} \mathrm{m}^{-1}\right)\end{array}$ & $\begin{array}{l}\text { Uranium } \\
\left(\mathrm{Bq} \mathrm{Kg}^{-1}\right)\end{array}$ \\
\hline January & $11,137.63$ & 504.53 & 7.066 & 4494.83 & 203.62 & 2.852 & 6921.24 & 313.53 & 4.391 \\
\hline March & 5210.82 & 236.05 & 3.306 & 5210.82 & 236.05 & 3.306 & 2704.85 & 122.53 & 1.716 \\
\hline May & 1193.32 & 54.06 & 0.757 & 1778.2 & 80.55 & 1.128 & 4693.71 & 212.63 & 2.978 \\
\hline July & 793.32 & 35.94 & 0.503 & 875.10 & 39.64 & 0.555 & 2674 & 121.13 & 1.696 \\
\hline September & 2398.04 & 108.63 & 1.522 & 2621.07 & 118.73 & 1.663 & 3357.43 & 152.09 & 2.13 \\
\hline November & $11,933.22$ & 540.57 & 7.571 & $11,137.63$ & 504.54 & 7.066 & $14,439.14$ & 654.09 & 9.161 \\
\hline Average & 5444.42 & 246.63 & 3.45 & 4352.99 & 197.19 & 2.76 & 5798.41 & 262.66 & 3.68 \\
\hline
\end{tabular}




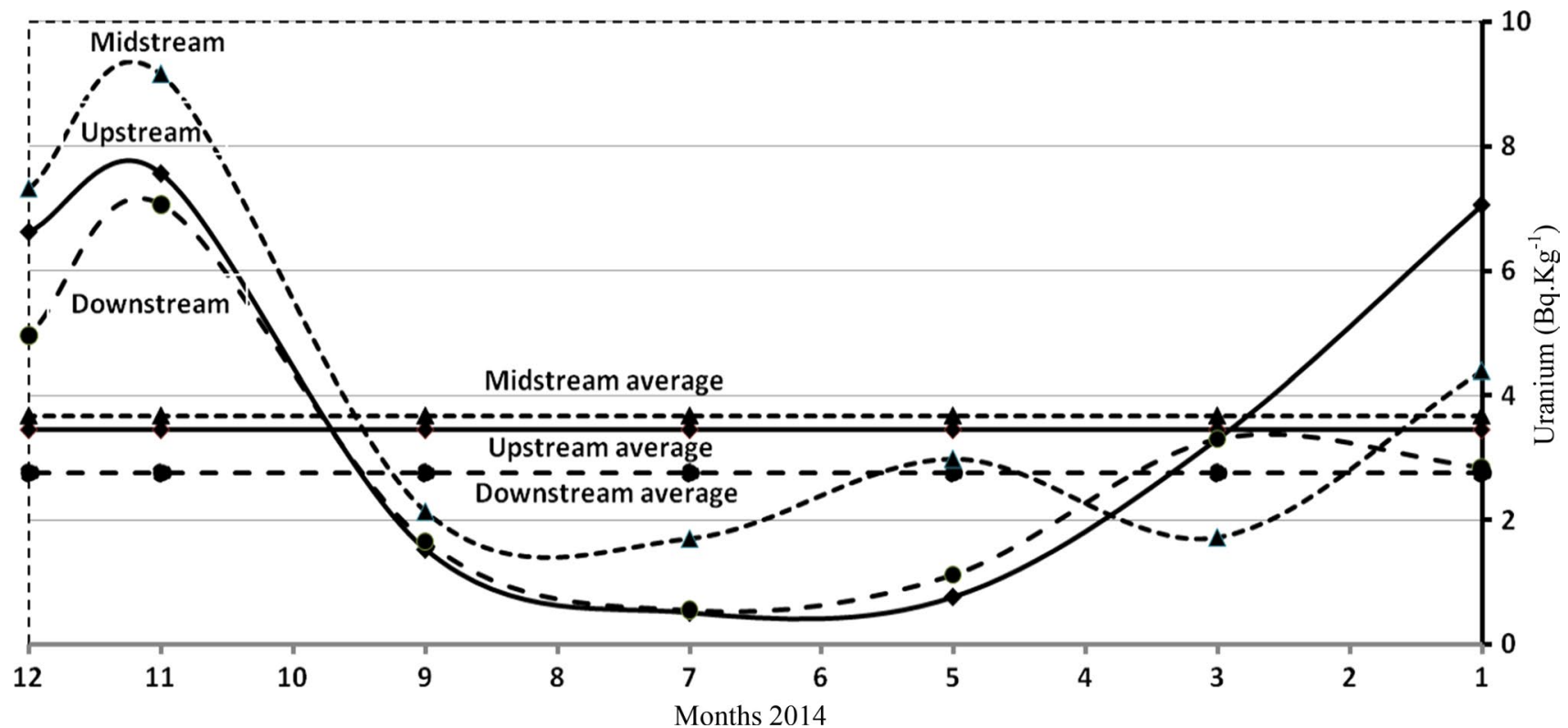

Fig. 3 Uranium contents $\left(\mathrm{Bq} \mathrm{Kg}^{-1}\right)$ of Tigris River sediment at a three sites along Baghdad city area during the period from November 2013 to June 2014

The higher calculated uranium contents were observed during winter months from November to January, 7.571, 7.066 and $9.161 \mathrm{~Bq} \mathrm{Kg}^{-1}$, and exceeding the average values many times. The lower values were obtained during summer months from May to September, with values ranging from 0.503 to $2.978 \mathrm{~Bq} \mathrm{Kg}^{-1}$, and they were less than the average values, as shown in Fig. 3.

This variation may be arisen due to the difference in the nature of the sediment samples and anthropogenic activities that affected ecosystem of the Tigris River (Al-Obaidy and Al-Khateeb 2013; Al-Nuzal et al. 2015). Furthermore, it was observed that uranium contents in the sediment samples were increased towards downstream of Baghdad city due to effects of huge human activities which increase the pollutants discharged to the river ( $\mathrm{Al}$ Obaidy et al. 2015; Al Obaidy et al. 2014). However, the increase in water level of Tigris River during the period from April due to the melting of snow in the Turkish mountainous region may be another key factor. Higher water stream will remove some of the settled sediments from the bottom of the river, provided that the samples were taken from 0 to $10 \mathrm{~cm}$ thickness. Higher water level can remove sediments from the river bottom; this mechanism will be partially responsible for increasing the radioactivity level at downstream of the river. Figure 2 clearly revealed that the upstream and downstream contents of uranium which are almost of the same magnitude during summer time.

\section{Conclusion}

The alpha radioactivities of the sediments, along Tigris River in Baghdad city area, were measured by using CR-39 SSNTD's. It was increased ongoing towards south of the city due to the effects of huge human activities. This difference was attributed to the nature of the sediment samples and anthropogenic activities. The highest measured alpha radioactivities were observed during winter months from November to January, while the lowest were during summer months from May to September. Higher water stream can remove sediments from the river bottom during summer.

Acknowledgements The authors wish to thank The University of Technology, Environmental Research Center for supporting the research work.

\section{Compliance with ethical standards}

Conflict of interest The authors declare that they have no conflict of interest.

Open Access This article is distributed under the terms of the Creative Commons Attribution 4.0 International License (http://creativeco mmons.org/licenses/by/4.0/), which permits unrestricted use, distribution, and reproduction in any medium, provided you give appropriate credit to the original author(s) and the source, provide a link to the Creative Commons license, and indicate if changes were made. 


\section{References}

Al Obaidy AHMJ, Talib AH, Zaki SR (2014) Environmental assessment of heavy metal distribution in sediments of Tigris river within Baghdad city. Int J Adv Res 2(8):947-952

Al Obaidy AHMJ, Talib AH, Zaki SR (2015) Application of water pollution index for assessment of Tigris river ecosystem. Int J Adv Res 3(2):219-223

Al Obaidy AHMJ, Al-Janabi ZZ, Al-Mashhady AAM (2016) Distribution of some heavy metals in sediments and water in tigris river. J Glob Ecol Environ 4(3):140-146

Al-Ansari NA, Knutsson S (2011) Toward prudent management of water 358 resources in Iraq. J Adv Sci Eng Res 1(53-67):359

Al-Ansari N, Ali S, Taqa A (1979) Sediment discharge of the river Tigris at Baghdad (Iraq). In: Canberra symposium: the hydrology of areas of low precipitation. Published by IAHS (International Association of Hydrological Science). Canberra

Ali AA, Al-Ansari NA, Knutsson S (2012a) Morphology of Tigris river within Baghdad city. Hydrol Earth Syst Sci 16:3783-3790

Ali AA, Al-Ansari NA, Knutsson S (2012) Impact of growing islands on the flood capacity of Tigris river in Baghdad city. ICSE6 Paris pp 27-31

Al-Lami AA, Al-Jaberi H (2002) Heavy metals in water, suspended particles and sediment of the upper-mid region of Tigris river, Iraq. In: International symposium on envrionmental pollution control and waste management, Tunis

Al-Nuzal SMD, Amin SA, Lami MHM, Jazaa BH (2015) Natural radioactivity level of phosphate fertilizers and related products from Al-Qaim complex plant in Iraq by using solid state nuclear track detector. Eng Technol J 34(3 Part (B)):394-404

Al-Obaidy AHMJ, Al-Khateeb M (2013) The challenges of water sustainability in Iraq. Eng Technol J 31(5):828-840

Al-Shahrabaly QM (2008) River discharges for Tigris and Euphrates gauging stations. Ministry of Water Resources, Baghdad

Barillon R, Klein D, Chambaudet A, Devillarade C (1993) Comparison of effectiveness of three radon detectors (LR-115, CR-39 and Cilicon Diode pin) placed in cylindrical device-theory and experimental techniques. Nucl Tracks Radiat Meas 22(1-4):281-282

Cogliano VJ, Baan R, Straif K, Grosse Y, Lauby-Secretan B, El Ghissassi F, Bouvard V, Benbrahim-Tallaa L, Guha N, Freeman C, Galichet L, Wild CP (2011) Preventable exposures associated with human cancers. J Natl Cancer Inst 103:1827-1839
Dries J, Bastiaens L, Springael D, Kuypers S, Agathos SN, Diels L (2005) Effect of humic acids on heavy metal removal by zerovalent iron in batch and continuous flow column systems. Water Res 39(15):3531-3540

El-Araby EH (2013) Environmental air dosimetry in some locations of Jazan using passive track detectors. J Life Sci Technol 1(1):78

Eugin Shaji J, Kannan C, Feroz Khan M (2012) Radioactivity measurements in river sediments and aquatic organisms of Kanyakumari district. In: Proceedings of the national seminar on current perspectives in biological sciences (NSOCPIBS - 2012)

Karadede-Akin Hülya, Ünlü Erhan (2007) Heavy metal concentration in water, sediments, fish, and some benthonic organisms from Tigris river, Turkey. Environ Monit Assess 131(1-3):323-337

Mantoura RFC, Dickson A, Riley JP (1978) The complexation of metals with humic materials in natural waters. Estuar Coast Mar Sci 6(4):387-408

Patiris DL, Tsabaris C, Anagnostou C, Androulakaki E, Pappa FK, Eleftheriou G, Sgouros G (2015) Radioactive isotopes' concentrations in the estuary of Tigris/Euphrates river. In: 11th panhellenic symposium on oceanography and fisheries, Mytilene, Lesvos island, Greece, 2015

Rahman MA, Abu Hasan Md, Rahim A, Shafiqul Alam AM (2010) Characterization of humic acid from the river bottom sediments of Burigonga: complexation studies of metals with humic acid. Pak J Anal Environ Chem 11(1):42-52

Sarma HK (2013) Radon activity and radon exhalation rates from some soil samples by using SSNTD. Int J Adv Res Electr Electron Instrum Eng 2(10):5024-5029

Selçuk Zorer O, Ceylan H, Doğru M (2009) Gross alpha and beta radioactivity concentration in water, soil, and sediments of Bendimahti River and Van Lake (Turkey). Environ Monit Assess 148(1-4):39-46

UN-ESCWA (United Nations Economic and Social Commission for Western Asia) and BGR (2013) Chapter 3: Tigris river basin. Inventory of Shared Water Resources in Western Asia-PART I, Beirut

United Nations Scientific Committee on the Effects of Atomic Radiation (UNSCEAR) (2012) Biological mechanisms of radiation actions at low doses. United Nation, New York

Publisher's Note Springer Nature remains neutral with regard to jurisdictional claims in published maps and institutional affiliations. 